\title{
correspondence
}

\section{Earth scientists}

SIR,-'European earth scientists disunite', an article by Peter J. Smith in your issue of April 12 is erroneous and misleading; we are concerned that such an article should have appeared in Nature without an attempt to check the facts.

The main tenor was implication of lack of coordination between the organisers of a forthcoming meeting in Reading of European Geological Societies (the Geological Society and the University of Reading) and the European Geophysical Society. In fact the minutes of the first meeting of the Policy Committee for the Meeting of European Geological Societies which is to take place from September 8-12, 1975, were sent in July 1973 to the Secretary of the European Geophysical Society at the Royal Society. A letter with his comments was received. It was certainly not "more or less by accident" that he discovered that there would be such a meeting. In December 1973 a special letter was sent to the President of the European Geophysical Society, with a copy to the Secretary, inviting participation of members of EGS and requesting their views and suggestions for topics for discussion. The letter was acknowledged by President Morelli welcoming the chance for cooperation, and expressing the hope that many members of the EGS would be interested in attending the Reading meeting.

For one whose professed anxiety is about the unity of earth science (that is, of geology) $\mathrm{Mr}$ Smith lays a surprising amount of emphasis on a distinction between geophysics and geology. We would expect him to recognise, as we have for many years, that geophysics is a necessary and important part of geology. Phrases such as "there being no such thing as the geology of the core" make semantic nonsense to stratigraphers, mineralogists and sedimentologists like us. Of course we agree that geophysicists, tectonicians, geochemists, palaeontologists, petrologists and the rest need to talk to one another: that is the object of the projected Reading meeting in 1975; we do not, however, see it as a matter for geophysicists on the one hand and "geologists" on the other. The theme chosen for the 1975 meeting, 'Europe from Crust to Core' is designed to secure the widest possible interdisciplinary discussion. As to the formation of a Pan-European Society of Earth Scientists, that is not the immediate object of the exercise, but if some of those attending wish to discuss such a possibility, so well and good.

Peter Kent

The Geological Society

of London

KingSLeY DUNHAM

Institute of Geological

Sciences, London

University of Reading Percival Allen

\section{Reply from Chile}

SIR, - In your journal (March 29) you published a letter sent to you by well known scientists who referred to the "dramatic conditions of the Chilean academic community". As these scientists have great influence in the scientific community, I must reply to such a letter.

I was in fact nominated as Rector of Universidad Católica de Chile by the Junta Militar de Gobierno, which designation was confirmed by a Decree of the head of the Catholic Church in Chile and Gran Cancillar of this University, Cardinal Raul Silva Henríquez. Nothing said in the letter referred to, corresponds to the real situation in this University since the day I assumed office, early in October, 1973.

Contracts of academics are not provisional as the letter suggests. It is true that some of them have been dismissed although no special Commission has existed for this purpose. They were dismissed because they simply abandoned their job or because they never anticipated in the academic life of this University or any other but preferred political activities instead of doing the work they were paid for.

In any case, the number of academics dismissed from this University is less than the figure of 65 quoted in the letter. This is out of a total of over 2,000 teachers. In all cases of dismissal full legal compensation has been paid. None are natural scientists; they all belong to the social sciences, mainly sociology and political science.

None of the 11,500 students in this community has been dismissed and so there has been no need of reregistration.

With regard to the staff in prison or executed, some teachers and administrators have indeed been questioned. Very few are still in prison (only 5) and legal procedures are followed to clarify their responsibilities for the crimes of which they are accused, according to traditional Chilean law. They have been allowed legal defence, as it is a long standing custom in Chile which nobody here has forgotten. As to the executions which they claim have happened, I would like to hear of one member of this University who has suffered, for I know of none.

As to the departments which have been dismantled, none of the examples given in the letter has occurred here. No Faculty or Institute has been closed except for two political centres whose Marxist political inspiration was dedicated to public indoctrination.

Nevertheless, I can say that those who judge us seem to ignore the facts and to forget our previous history. They have not considered at all what has really happened in the University. They have not considered that the Supreme Court and the Congress had previously declared the former government illegal, nor that our Armed Forces have historically been politically neutral, nor the people's claim over the last two years to remove the Marxist regime which was destroying all our rights and most beloved traditions. Scientists particularly, should be aware that proof is required before any decision. Nobody should say anything which he may regret the next day; nobody should allow themselves to be the instrument of others hidden intentions.

In this sense, I trust that time and history will establish what really happened in this country, despite all intentional and international campaigns against Chile.

JoRGe Swett MADGE

Universidad Catolica de Chile,

Santiago, Chile

\section{Penicillin}

SIR,_Y Your article (Nature, May 24) on cancer research by Brian Ford contains the statement that it was the war effort and directed research which gave us penicillin. This statement is incorrect. The reinvestigation of penicillin which led to the discovery of its curative properties was started in 1938 . well before the outbreak of the war, and its aim was not the practical one of discovering a new chemotherapeutic agent.

ERNST CHAIN

Department of Biochemistry,

Imperial College of Science and Technology,

London, SW7, UK 